\title{
Numerické zpracování výsledků expertních analýz pomocí matice rizik
}

\author{
Numerical Processing of Results of Expert Analysis with Usage Risk Matrix
}

\author{
Petr Šimůnek ${ }^{\mathrm{a}^{*}}$, Ivana Laníkováa ${ }^{\mathrm{a}}$ Petr Štěpánek ${ }^{\mathrm{a}}$, Jakub Venclovskýa ${ }^{\mathrm{a}}$, Lukáš Junek ${ }^{\mathrm{b}}$ \\ 'Vysoké učeni technické v Brně, Fakulta stavební \\ ${ }^{b}$ Vysoké učeni technické v Brně, Fakulta strojního inženýrství
}

\begin{abstract}
Abstrakt
Článek se zabývá možnostmi numerického zpracování expertních analýz při použití matice rizik. Pro obvyklý způsob výpočtu rizika není běžná podoba matice rizik odpovídající. Pro často používanou podobu matice rizika je navržen modifkovaný výpočet rizika. V článku jsou popsány varianty numerických výstupů z matice rizik, mimo jiné pomocí nástrojů fuzzy logiky. Př́spěvek byl prezentován na konferenci ExFoS 2019 ve dnech 24.-25. ledna 2019.
\end{abstract}

Klíčová slova: matice rizik, expertní analýzy, fuzzy logika, riziko, hodnocení.

\section{1. ÚVOD}

Autoři se zabývají komplexní analýzou životnosti technických objektů. Průběh hodnocení se skládá z několika kroků, jedním z nich je hodnocení rizika pomocí matice rizik. Do ní vstupují hodnoty vyjadřující míru pravděpodobnosti poruchy (index pravděpodobnosti vzniku poruchy; lze popsat také jako potenciál ke vzniku poruchy) a velikosti dopadů na sledované funkce objektu při vzniku poruchy (index následků, dopadu).

Popsané indexy jsou vypočteny z výsledků expertní analýzy, která hodnotí jednotlivé rizikové faktory pomocí diskrétních hodnot v oboru celých kladných čísel; např. v intervalu od 1 do 5 . Vyšší hodnota odpovídá vyšší míře pravděpodobnosti poruchy a vyššímu dopadu poruchy na funkci konstrukce. Vypočtené indexy mohou být normovány, např. $\mathrm{v}$ intervalu $<0,1>$.

Při vyhodnocování výše míry nebo hodnoty rizika (v závislosti na formě vyjádření pravděpodobnosti a dopadu) pomocí matice rizik je možné použít kromě kvalitativního výstupu také kvantitativní. Některé př́stupy výpočtu míry rizika z matice rizik jsou popsány níže.

\begin{abstract}
The article deals with possibilities of numerical processing of expert analysis using a risk matrix. The usual form of risk matrix is not corresponding for the ordinary way of the risk rate calculating. A modified rate risk calculation is designed for the frequently used form of risk matrix. Variants of numerical output data form from the risk matrix are described, using fuzzy logic tools, among other things. The paper was presented at the ExFoS 2019 conference, 24-25 ${ }^{\text {th }}$ January.
\end{abstract}

Keywords: risk matrix, expert analyses, fuzzy logic, risk, assessment.

\section{KVANTITATIVNÍ HODNOCENÍ RIZIKA A MATICE RIZIK}

\subsection{Definice rizika a matice rizik}

Riziko $R$ je definováno na základě pravděpodobnosti (nebo míry pravděpodobnosti) $P$ vzniku nežádoucí události a významnosti následků realizace scénáře této nežádoucí události $D$, obvykle je definováno vztahem

$$
R=P \times D
$$

Vyjádření míry nebo hodnoty rizika se provádí kvalitativně nebo kvantitativně a je předmětem rizikové expertní analýzy.

Matice rizik v obvyklé podobě je semi-kvantitativní nástroj k určení hodnoty nebo míry rizika. Pro vyhodnocení této obvyklé podoby matice rizik nejsou nutné specifické znalosti a zkušenosti, použití je relativně snadné a efektivní, je častou součástí rizikových analýz v různých oborech. Matice rizika má ovšem svá matematická a logická omezení, viz [3]. 


\subsection{Kvantitativní hodnocení rizika při použití matice rizik podle definice rizika}

$\mathrm{V}$ př́ípadě, že riziko počítáme na základě vztahu (1), lze funkci rizika vyjádřit jako plochu ve tvaru hyperbolického paraboloidu, viz obr. 1. Při tomto př́stupu nejsou hodnoty funkce míry rizika $\mathrm{v}$ daném intervalu rovnoměrně rozděleny, dobře patrné je to na půdorysném průmětu izolinií plochy rizika viz obr. 1 a obr. 2 . Pokud mají číselné hodnoty vycházející z matice rizik odpovídat předpokladu výpočtu podle vztahu (1), měla by matice být

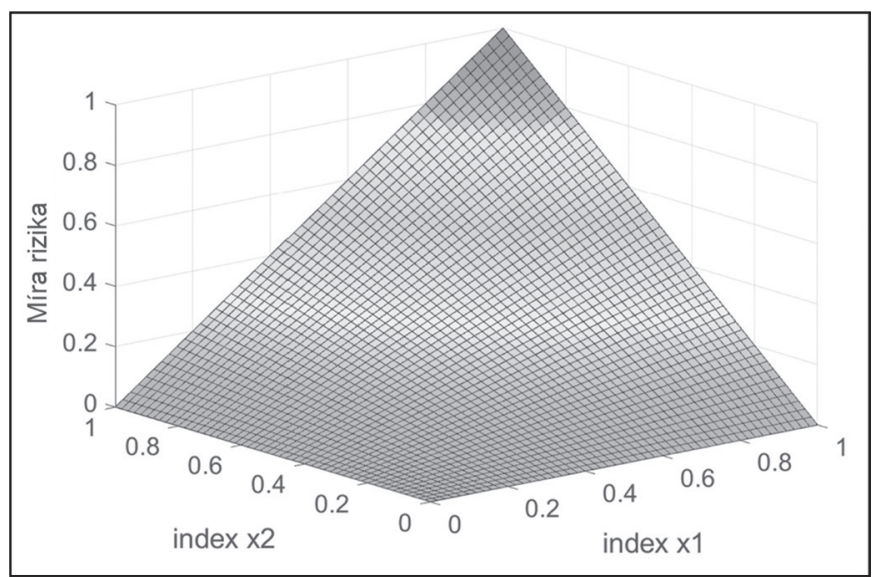

Obr. 1 Plocha miry rizik vztahu [1].

Fig. 1 - Risk surface according to eq. [1].

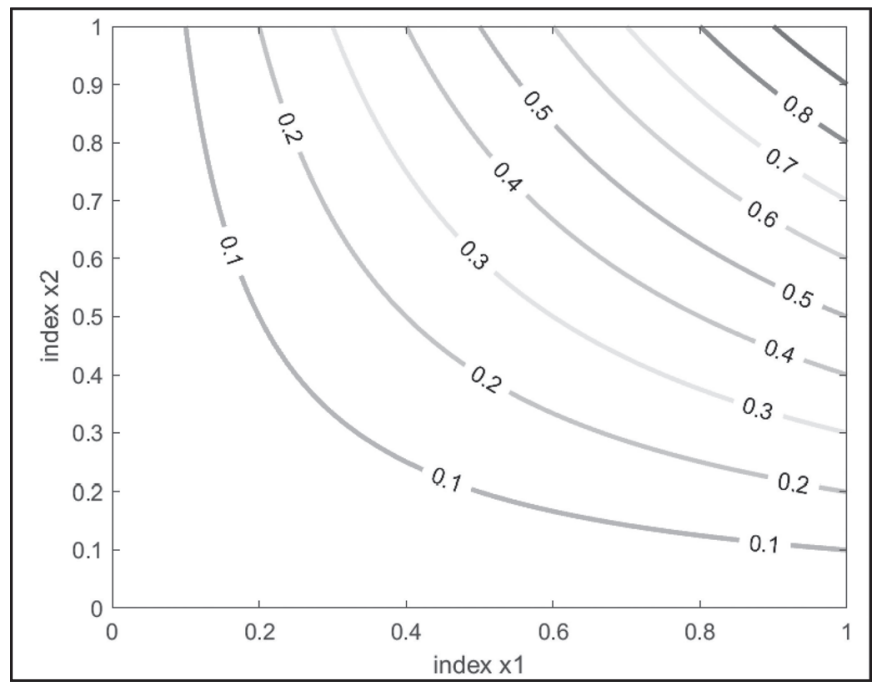

Obr. 2 Průběh míry rizika, izolinie plochy z obr. 1.

Fig. 2 Risk layout distribution, isolines in accordance to Fig. 1 rozvržena dle průběhu izolinií míry rizika z obr. 2. Př́́klad takové matice rizik pro tři kvalitativní stupně míry rizika je uveden $v$ tab. 1 .

Matice v tab. 1 vyjadřuje tři úrovně míry rizika. Při kvalitativním rozlišení míry rizika je použita následující škála rizika: zanedbatelné , střední $\square$ a vysoké

\subsection{Modifikace výpočtu rizika}

Na rozdíl od matice rizik zobrazené $\mathrm{v}$ Tab. 1 má většina používaných matic hodnoty nebo míry rizik rozděleny přibližně rovnoměrně, např. tab. 2 . Tomuto rozložení rizik ale neodpovídá výpočet rizika podle vztahu (1). Jednoduchou úpravou vztahu (1) se můžeme této podobě rozložení rizika $\mathrm{v}$ matici přiblížit:

$$
R=\sqrt{P \times D} .
$$

Po takové úpravě výpočtu (a tedy i definice) rizika se nezmění (v porovnání se vztahem (1)) rozsah číselného vyjádření míry rizika (v intervalu $0-1$ ) ale rozložení číselného vyjádření rizika $\mathrm{v}$ daném intervalu.

Míry modifikovaného rizika dle vztahu (2) jsou vyjádřeny v podobě plochy na obr. 3. Rovnoměrné rozložení míry modifikovaného rizika je patrné z průběhu izolinií plochy na obr. 4. Rozložení dle obr. 4 mnohem lépe vystihuje podobu matice $\mathrm{v}$ tab. 2 (podoba matice, kterou autoři použili při jedné z praktických analýz). Můžeme tedy získat kvantitativní výstup z matice rizik, ale neměli bychom již mluvit o riziku (jeho číselném vyjádření) tak jej chápeme dle definice ve vztahu (1). Ale ani úpravou dle vztahu

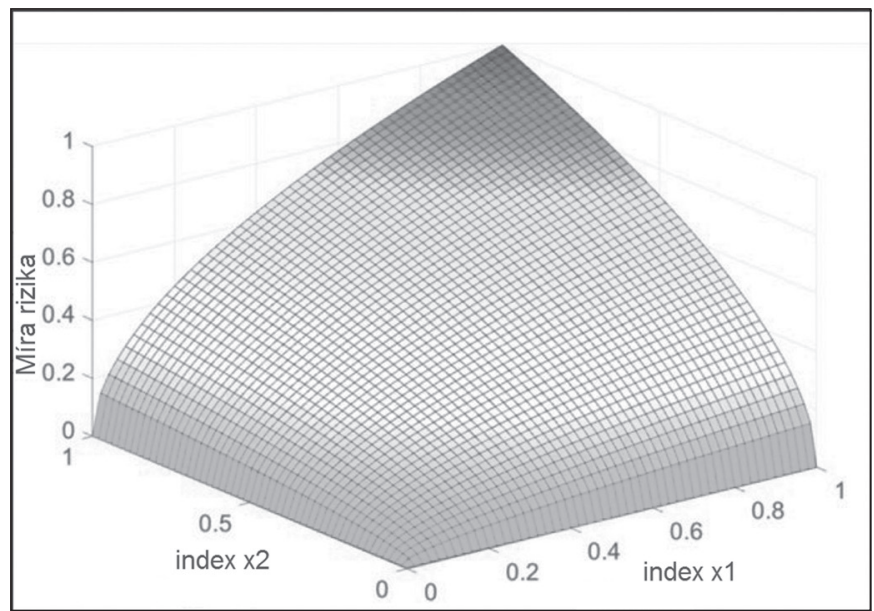

Obr. 3 Plocha miry rizik dle modifikovaného vztahu pro výpočet rizika [2].

Fig. 3 Modified Risk surface in accordance with eq. [2].

Tab. $15 \times 5$ Matice rizik, která odpovídá definici rizika dle vztahu (1), [3].

Tab. $15 \times 5$ Matrix Compatible with Risk $=$ Probability $\times$ Consequence [3].

\begin{tabular}{|c|c|c|c|c|c|}
\hline $\begin{array}{r}\text { Pravděpodobnost (index X1)/ } \\
\text { /dopad (index X2) } \\
\end{array}$ & $0-0,2$ & $0,2-0,4$ & $0,4-0,6$ & $0,6-0,8$ & $0,8-1$ \\
\hline \multicolumn{6}{|l|}{$0,8-1$} \\
\hline \multicolumn{6}{|l|}{$0,6-0,8$} \\
\hline \multicolumn{6}{|l|}{$0,4-0,6$} \\
\hline \multicolumn{6}{|l|}{$0,2-0,4$} \\
\hline $0-0,2$ & & & & & \\
\hline
\end{tabular}


Tab. 2 Matice rizik.

Tab. 2 Risk Matrix.

\begin{tabular}{|c|c|c|c|c|c|}
\hline \multicolumn{6}{|c|}{ Riziko } \\
\hline$\nexists=$ & $0,75-1$ & Nízká & Střední & Vysoká & Vysok \\
\hline$\overline{0}$ & $0,5-0,75$ & Nízká & Střední & Střední & Vysoké \\
\hline x. 0 , 㱟 & $0,25-0,5$ & Zanedbatelná & Nízká & Střední & Středn \\
\hline 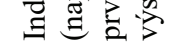 & $<0,25$ & Zanedbatelná & Zanedbatelná & Nízká & Nízká \\
\hline
\end{tabular}

Index X1 (např. významnost rizikového faktoru)

$<0,25$

$0,25-0,5$

$0,5-0,75$

$0,75-1$

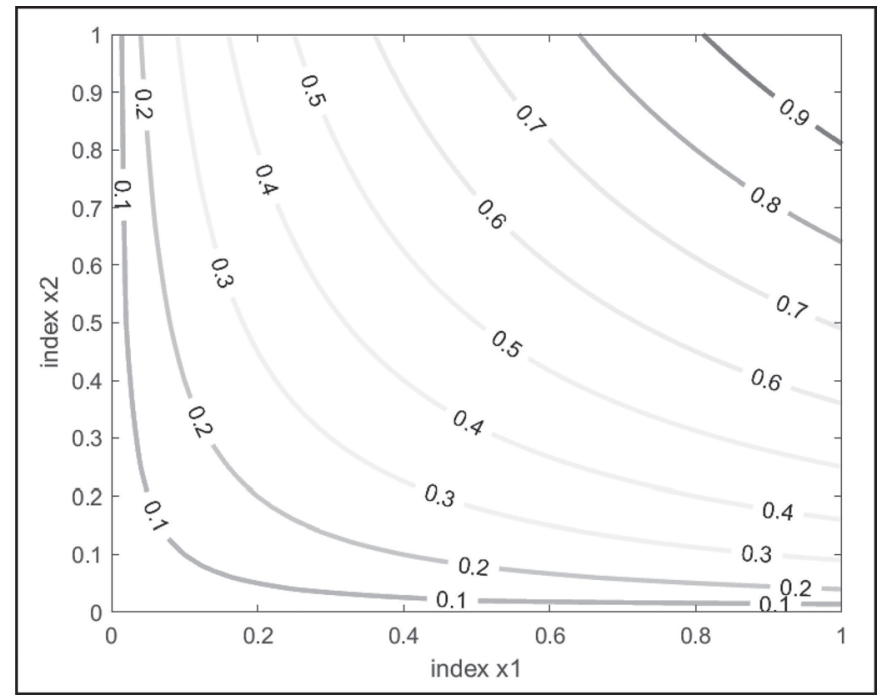

Obr. 4 Průběh miry modifikovaného rizika, izolinie plochy z obr. 3. Fig. 4 Modified Risk distribution (layout), isolines in accordance to Fig.3.

(2) nemusíme dostat uspokojivé kvantitativní hodnoty odpovídající použité matici.

\subsection{Využití př́istupu fuzzy logiky při kvantitativní hodnocení rizika pomocí matice rizik}

$\mathrm{V}$ prŕípadě specifické podoby matice rizik, u které nelze použít výše popsané př́stupy a analytické řešení je obtížné nebo dokonce nemožné, lze použít nástrojů fuzzy logiky.

Při tomto prŕstupu dostaneme kvantitativní výstup z matice rizik, ale opět se nejedná o riziko vypočtené dle definice ve vztahu (1).

Využití fuzzy logiky pro vyhodnocení rizika pomocí matrice rizik již bylo použito v řadě případů, viz např. [1] a [2].

Vstupními veličinami jsou (stejně jako u matice rizik) míra pravděpodobnosti a dopady (při uvažovaném vzniku nežádoucí události). Členění vstupních veličin odpovídá členění matice rizik. $V$ dále popisovaném modelovém př́padu jsou stupně veličin (v úvodu popsané indexy) rozčleněny podle matice v tab. 2.

Každý stupeň je vyjádřen pomocí funkce příslušnosti, která vyjadřuje průběh hodnoty indexu v daném intervalu, viz obr. 5. Pro indexy X1 a X2 jsou v tomto př́padě nadefinovány čtyři funkce př́slušnosti.

Dalším krokem je provedení fuzzifikace, tj. převedení reálné proměnné do jazykové proměnné. Pro fuzzifikaci byly použity funkce př́slušnosti lichoběžníkového tvaru. Pro vyjádření hodnoty rizika
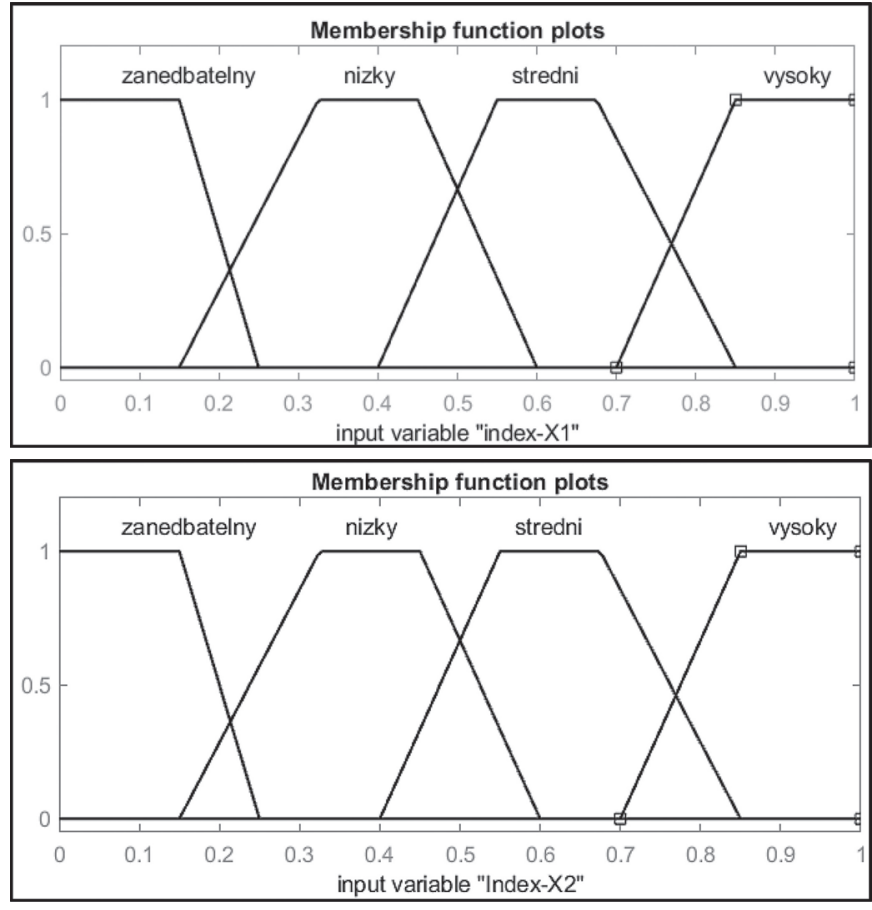

Obr. 5 Funkce príslušnosti pro indexy X1 a X2.

Fig. 5 Membership Function for index X1 and X2.

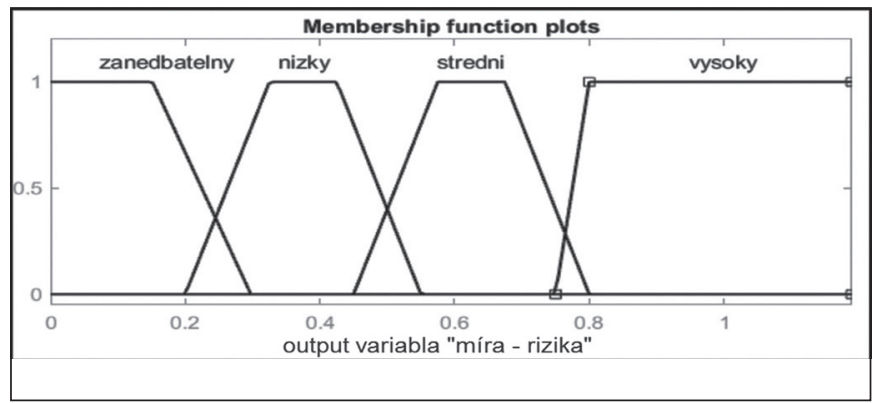

Obr. 6 Funkce př́slušnosti pro výstup - vyjadřjící míru rizika.

Fig. 6 Membership Function for output describing risk value.

v matici rizik byla použita fuzzy metoda použití složené podmínky spojené logickými spojkami, konkrétně v tomto př́ípadě AND.

Podle úrovní rizika $\mathrm{v}$ matici rizik (např. podle matice uvedené v tab. 2, tj. riziko zanedbatelné, nízké, střední, vysoké) se definuje funkce př́slušnosti pro výstup, viz obr. 6.

Dalším krokem je určení pravidel pro vyhodnocování pomocí fuzzy logiky. Každé dvojici (kombinaci) vstupních funkcí př́slušnosti, složené $\mathrm{z}$ jedné funkce př́íslušnosti indexu X1 a jedné 


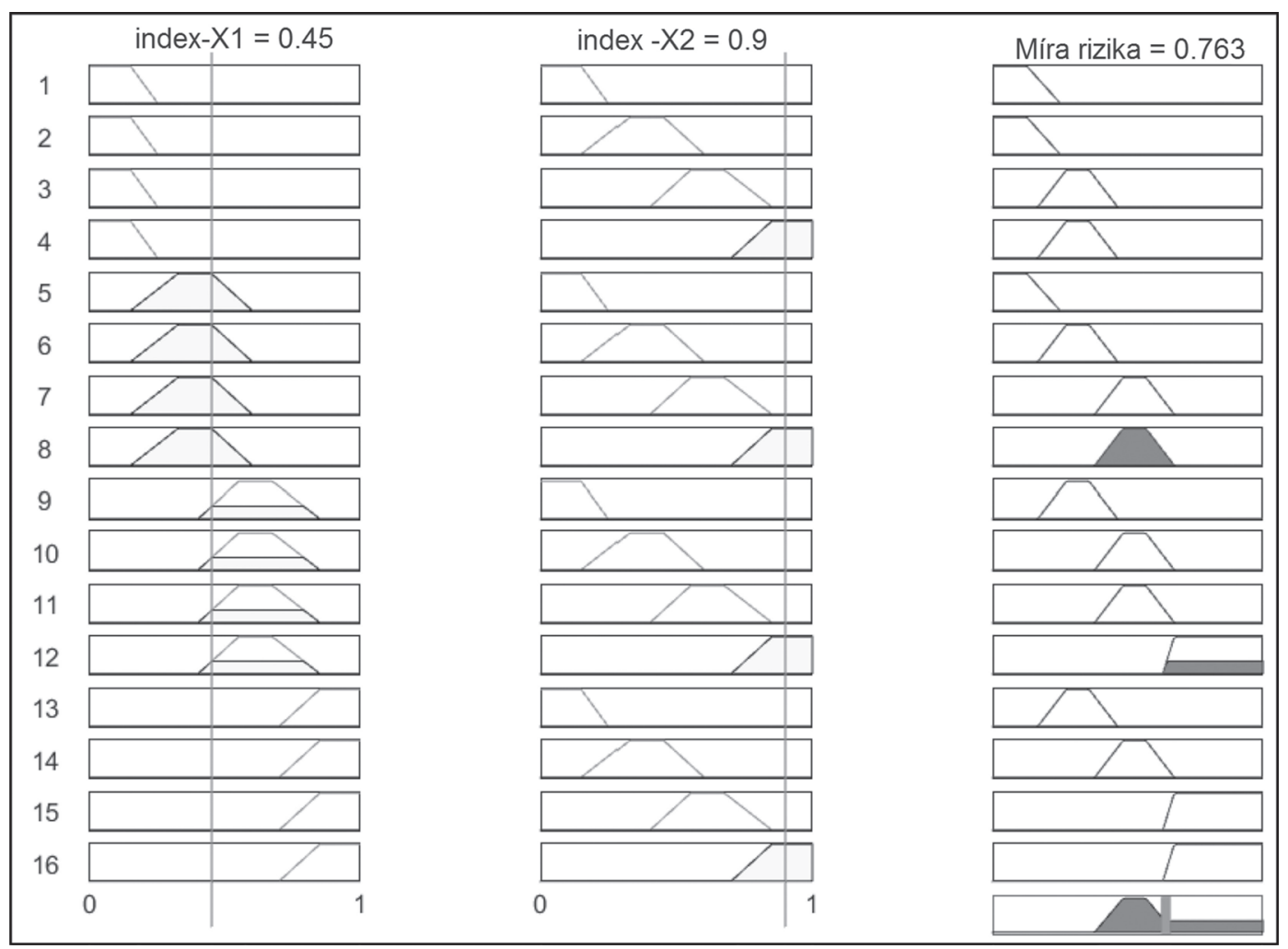

Obr. 7 Pravidla pro vyhodnocování pomoci fuzzy logiky.

Fig. 7 Combination rules of input and output membership functions.

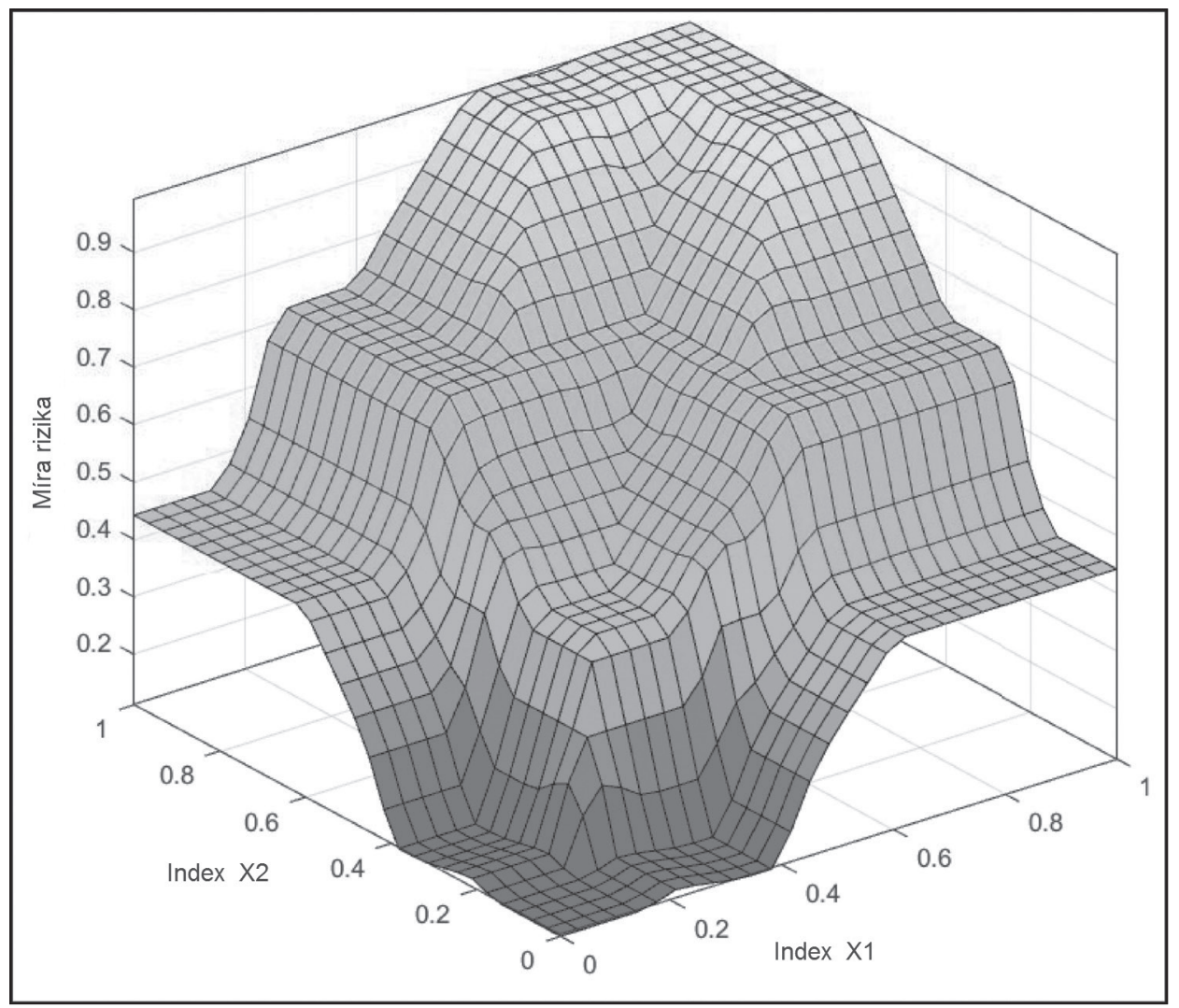

Obr. 8 Plocha hodnot míry rizika hodnoceného jevu.

Fig. 8 Risk rate surface. 
funkce příslušnosti indexu X2, se přiřadí jedna z výstupních funkcí př́slušnosti vyjadřující hodnotu rizika (v souladu s podobou matice), viz obr. 7.

Pro nadefinované vstupní funkce př́slušnosti pro X1 (4 funkce) a X2 (4 funkce) na obr. 5, je možných 16 dvojic a musí odpovídat dimenzi matice rizik, $\mathrm{tj}$. $v$ našem př́ípadě typu $4 \times 4$, viz tab. 2 . Konkrétní pravidla pro vyhodnocování všech dvojic vstupních funkcí př́íslušnosti, která byla použitá $\mathrm{v}$ tomto př́kladu, jsou uvedena na obr. 7: v prvním sloupci je číslo pravidla, ve druhém sloupci jsou vstupní funkce př́islušností pro index X1, ve třetím sloupci jsou vstupní funkce př́islušnosti pro index X2 a ve čtvrtém sloupci jsou přiřazené funkce příslušnosti pro výstup.

Posledním krokem je defuzzifikace, tj. převod jazykových proměnných do reálných proměnných. Pro modelový případ bylo použito transformačního postupu na principu těžiště (viz obr. 7: poslední sloupec pod pravidly pro vyhodnocování).

Výstupní hodnoty z výše popsaného procesu jsou vyobrazeny ve formě plochy hodnot rizika a jsou znázorněny na obr. 8 .

Při použití fuzzy množin je výhodou, že příslušnost prvku k dané množině (buňce matice) může být odstupňována. Lze je použít k popisu pravděpodobných, nejistých nebo neurčitých jevů.

Nejobtížnější část hodnocení pomocí fuzzy logiky je správná intepretace vstupních veličin a přiřazení vhodné funkce příslušnosti.

Aplikace fuzzy logiky byla provedena pomocí programu Matlab [5].

\section{ZÁVĚR}

Při kvantitativním vyhodnocení matice rizik je nezbytné respektovat způsob výpočtu rizika (definici rizika). Při vyjádření rizika dle obvyklého způsobu dle vztahu (1) je nutné použít matici s odpovídajícím rozložením a mírou nebo hodnotou rizika, viz tab. 1. Při použití více běžné přibližně symetrické matice rizik lze pro kvantitativní vyhodnocení využít vztahu (2). Pro obecné podoby matic rizik je možné použít nástroje fuzzy logiky. Tento přístup lze také použít $\mathrm{k}$ popisu pravděpodobných, nejistých nebo neurčitých jevů.

Použití analogických přístupů je jednoduché a rychlé, jsou ale omezeny na konkrétní podoby matic rizik. Nevýhodou použití fuzzy logiky je vyšší pracnost (ve srovnání s výše uvedenými postupy).

\section{Poděkování}

Př́íspěvek byl vytvořen v rámci řešení projektu č. TH02020781 „Management spolehlivosti a životnosti stavebních konstrukcí v jaderné energetice“ podporovaného TAČR a projektu č. LO1408 „AdMaS UP - Pokročilé stavební materiály, konstrukce a technologie" podporovaného Ministerstvem školství, mládeže a tělovýchovy v rámci účelové podpory programu „Národní program udržitelnosti I“.

\section{LITERATURA}

[1] MARKOWSKI, A. S., MANNAN, M. S.: Fuzzy risk matrix. Journal of Hazardous Materials, 159(1), 2008, s. 152-157. ISSN 0304-3894.

[2] BAO, C., LI, J., WU, D.: A fuzzy mapping framework for risk aggregation based on risk matrices. Journal of Risk Research, 21(5), s. 539-561. ISSN 13669877.

[3] COX, L., A. What's Wrong with Risk Matrices? Risk Analysis, 28(2), 2008, s. 497-512. ISSN 1539-6924.

[4] KABIR, S., PAPADOPOULOS Y. A review of applications of fuzzy sets to safety and reliability engineering. International Journal of Approximate Reasoning, 100, 2018, s 29-55. ISSN 0888-613X

[5] Matlab R2018.

[6] ŠIMŮNEK, P., LANÍKOVÁ, I., ŠTĚPÁNEK, P. et al. Numerické zpracování výsledků expertních analýz pomocí matice rizik. In: Sbornik přispěvků konference Expert Forensic Science Brno 2019. VUT v Brně, 2019, s. 620-627. ISBN 978-80-214-5708-9.

\section{Správná citace:}

ŠIMŮNEK, P., LANÍKOVÁI., ŠTĚPÁNEK, P., VENCLOVSKÝ, J., JUNEK, L. Numerické zpracování výsledků expertních analýz pomocí matice rizik. Soudní inženýrství, 2019, 30(3), 46-50. DOI: http://dx.doi.org./10.13164/SI.2019.3.46. ISSN 1211-443X. 